\title{
Effect of Fertilizers (Urea, Farmyard and Chicken Manure) on Growth and Yield of Rhodes Grass (Chloris Gayana L. Knuth.)
}

\author{
Ahmed M. Yossif, Yassin M. Ibrahim* \\ Agronomy Department, Faculty of Agricultural Studies, Sudan University of Science and Technology Khartoum, Shambat, Sudan \\ *Corresponding Author: dagash501@yahoo.com
}

Copyright (C) 2013 Horizon Research Publishing All rights reserved.

\begin{abstract}
Abtract A field experiment was conducted during (2009/2010) season in Demonstration Farm of the Faculty of Agricultural Studies, Sudan University of Science and Technology at Shambat, Sudan. The objective was to study the effect of fertilizers (urea, farmyard and chicken manure) on growth and yield of Rhodes grass. The fertilizer treatments used in this study were urea [U $(100 \mathrm{KgN} / \mathrm{ha})]$, farmyard manure [FYM (5ton/ha)], chicken manure [ CHM (3ton/ha)], combinations between them (U+FYM, U+CHM, FYM+CHM, and U+FTM+CHM) with 8 cuts (Two months for the first cut and monthly after that to $8^{\text {th }}$ cut). The experiment was laied out in Randomized Complete Block Design (RCBD) with three replicates. The results revealed that growth parameters were not significantly affected by fertilizers except plant population but yield parameters were significantly affected by fertilizers.
\end{abstract}

Keywords Rhodes Grass, Fertilizers, Sudan

\section{Introduction}

Forage production is gaining more attention in the tropics and subtropics; in both developed and developing countries. New species, varieties and cultivars of forage and pasture plant have been introduced from areas and countries rich in forage and pasture plant to areas where they are scare. In Sudan forage production is very important because the forage is basic source of energy for growth and maintenance and product increment of livestock. Additionally, it is important due to the fact that Sudan has a huge number of animals which is estimated to about 143 million heads in 1998 (63 m goats, $42 \mathrm{~m}$ sheep, $35 \mathrm{~m}$ cattle and $3 \mathrm{~m}$ camels) (Mohammed, 2000).

Rhodes grass (Chloris gayana L. Kunth.) is a summer-growing, stoloniferous perennial, whose runners provide good soils, from infertile sands to fertile brigalow clays. It is difficult to established and have persistent on heavy cracking clay soils. Rhodes grass is one of the best grasses for rotation land in tropical and subtropical areas, useful for establishment pasture leys. It is suitable for silage and hay like by all kinds of stock but may causes skin trouble in horses. It's ability to establish rapidly makes it valuable for soil conservation (Reed, 1976).

Burhan and Hago (2000) stated that nitrogen plays an important role in plant growth and physiological processes, as it enters all enzymes composition and enhances vegetative growth and yield. Valenzuela and smith (2002) found that Rhodes grass responded well to nitrogen fertilizer after a basic pre-plant phosphorus application. Application of 50-60 $1 \mathrm{~b} /$ acre nitrogen when seedlings are 4-8 inch's tall gives vigorous stand. Khair (1999) pointed out that Rhodes grass responded well to $\mathrm{N}$ fertilization when applied in a separate dose after any harvesting Gasim (2001) found that the increase in $\mathrm{N}$ fertilizer increased leaf area and leaf to stem ratio of maize forage. Brima (2007) stated that mean number of leaves per plant of Rhodes grass was significantly affected by NPK but mean plant height, leaf area index and leaf to stem ratio were not significantly affected by NPK. Abedelrahman (2007) reported that no significant effect of nitrogen fertilizer was detected on mean plant height of Rhodes grass in the first and second cuts and Saad (2009) found a significant effect of nitrogen fertilizer on mean plant height. Abass (2007) stated that all fertilizers treatment had significant effect on fodder yield (fresh and dry), compared to control in (Sorghum bicolor L. Moench) and (Sorghum Sudanese).

The manure produced on extensively grazed land is not available for application to the arable crop. Manure is bulky, odorous, difficult and extensive to store, handle and transport. Therefore, the ease of fertilizer use has some time let to neglect -- the use of organic materials in agriculture. However, in general, surveys showed that farmers apply manure and compost where they are available and where there is adequate labour to collect, store and spread them (FAO, 2006). Obied (2003) and Ismael (2007)-- reported that manure was significantly increased the yield of different 
forage. Organic manures are composed mainly of wasted and residues from plant and animal. They contain much carbon and relatively small percentage of plant food; usually those come from the plant that fixed the carbon (Elawad, 2004). Elzelal (2002) showed that chicken manure applied at comparatively high rate; substantially increase the yield of dry matter plant. Irshad (2002) reported that the application of composted manure fertilizer enhanced plant growth and nutrient uptake compared with non-treated control. Maize growth was better under fertilizer than under composed manure. The objective was to study the effect of fertilizers (urea, farmyard and chicken manure) on growth and yield of Rhodes grass.

\section{Material and Methods}

A field experiment was conducted during (2009/2010) season in Demonstration Farm of the Faculty of Agricultural Studies, Sudan University of Science and Technology at Shambat, Sudan, to study the effect of fertilizers (urea, farmyard and chicken manure) on growth and yield of Rhodes grass. The experimental site lies at latitude $15^{\circ} 40 \mathrm{~N}$, longitude $32^{\circ} 40^{\prime} \mathrm{E}$ and 280 meters above sea level. The climate of the locality is semi-desert (Adam, 1996). The soil is alkaline $(\mathrm{pH} 8.0)$, cracking clay with about $50 \%$ clay content. It contains about $0.065 \%$ nitrogen $(\mathrm{N}), 0.230 \mathrm{meq} / \mathrm{L}$ potassium $(\mathrm{K})$ and $0.193 \mathrm{meq} / \mathrm{L}$ available phosphorus $(\mathrm{P})$ as determined by El Basari (1999). The treatments composed of three fertilization treatments $100 \mathrm{~kg} \mathrm{~N} / \mathrm{ha}$ urea $(\mathrm{U}), 5$ ton $/ \mathrm{ha}$ farmyard manure (FYM), 3ton/ha chicken manure (CHM) and combinations $(\mathrm{U}+\mathrm{F}, \mathrm{U}+\mathrm{CHM}, \mathrm{FYM}+\mathrm{CHM}$ and $\mathrm{U}+\mathrm{FYM}+\mathrm{CHM}$ ) and no fertilizer as the control, in three replications. Treatments were arranged in a Randomize Complete Block Design (RCBD) with 8 cuts (The first cut was harvested after two mnothes and the others were mnothly.

The forage was sown on $1^{\text {st }}$ June 2009 to $1^{\text {st }}$ March 2010 and the fertilizer treatments were applied at sowing. Plant height, number of leaves per plant, plant population, Leaf area index and leaf to stem ratio were measured as growth parameters and fresh wieght addition to dry weight were measured as yield parameters. The data were statistically analyzed by Computer program (M STAT-C) (1989). Means separation was performed by using LSD (Least Significant Differance) procedure.

\section{Results and Discussion}

Plant population (Table 1)and yield parameters (fresh weight,table2 and dry weight,table3 ) were significantly affected by fertilizers. Similar results were reported by Abass (2007) who stated that all fertilizers treatment had significant effect on fodder yield (fresh and dry). Other similar finding by Abdelrahman (2007) stated that forage dry wieght was significant influenced by increased in NPK fertilization levels and Ismael (2007) reported that manure significantly increased the yield of different forages.

Table 1. The effect of different fertilizers on Plant Population during2009/2010

\begin{tabular}{|c|c|c|c|c|c|c|c|c|}
\hline \multirow{2}{*}{ Treatments } & \multicolumn{8}{|c|}{ No. of Cuts } \\
\hline & 1 & 2 & 3 & 4 & 5 & 6 & 7 & 8 \\
\hline Urea (U) & 520 & 477 & 559 & 639 & 316 & 532 & 263 & 356 \\
\hline Farmyard Manure (FYM) & 418 & 605 & 889 & 750 & 347 & 461 & 183 & 376 \\
\hline Chicken Manure (CHM) & 478 & 693 & 848 & 1057 & 522 & 569 & 281 & 605 \\
\hline $\mathrm{U}+\mathrm{FYM}$ & 522 & 641 & 737 & 882 & 569 & 568 & 290 & 638 \\
\hline $\mathrm{U}+\mathrm{CHM}$ & 453 & 576 & 761 & 635 & 302 & 580 & 317 & 516 \\
\hline $\mathrm{FYM}+\mathrm{CHM}$ & 503 & 661 & 878 & 875 & 456 & 589 & 241 & 485 \\
\hline $\mathrm{U}+\mathrm{FYM}+\mathrm{CHM}$ & 498 & 687 & 811 & 822 & 362 & 767 & 251 & 548 \\
\hline Control & 517 & 537 & 897 & 867 & 258 & 440 & 267 & 406 \\
\hline LSD 5\% & 119.11 & 226.75 & 322.13 & 365.13 & 291.81 & 354.82 & 147.67 & 284.58 \\
\hline C.V & 13.91 & 21.25 & 23.07 & 25.69 & 44.45 & 36.79 & 43.01 & 33.09 \\
\hline $\mathrm{SE} \pm$ & 68.01 & 129.48 & 183.95 & 208.50 & 166.63 & 202.61 & 107.17 & 162.50 \\
\hline
\end{tabular}


Table 2. The effect of different fertilizers on Fresh Yield (ton/ha) during2009/2010

\begin{tabular}{|c|c|c|c|c|c|c|c|c|}
\hline \multirow[b]{2}{*}{ Treatments } & \multicolumn{8}{|c|}{ No. of Cuts } \\
\hline & 1 & 2 & 3 & 4 & 5 & 6 & 7 & 8 \\
\hline Urea (U) & 42.86 & 20.28 & 22.00 & 25.47 & 9.53 & 14.52 & 10.00 & 7.14 \\
\hline Farmyard Manure (FYM) & 26.90 & 27.38 & 29.19 & 23.81 & 9.28 & 7.86 & 7.62 & 10.00 \\
\hline Chicken Manure (CHM) & 44.05 & 33.95 & 38.71 & 37.62 & 13.10 & 9.76 & 9.28 & 12.62 \\
\hline U+FYM & 39.29 & 26.19 & 30.33 & 29.67 & 18.81 & 15.24 & 10.72 & 13.57 \\
\hline $\mathrm{U}+\mathrm{CHM}$ & 42.86 & 35.14 & 30.38 & 23.81 & 10.00 & 12.86 & 12.62 & 13.33 \\
\hline $\mathrm{FYM}+\mathrm{CHM}$ & 45.24 & 31.57 & 41.05 & 32.81 & 17.62 & 12.14 & 10.24 & 13.57 \\
\hline $\mathrm{U}+\mathrm{FYM}+\mathrm{CHM}$ & 45.24 & 31.00 & 35.71 & 33.81 & 15.24 & 15.00 & 10.71 & 10.24 \\
\hline Control & 40.48 & 22.62 & 28.57 & 27.38 & 8.09 & 12.62 & 10.67 & 9.28 \\
\hline LSD 5\% & 13.15 & 12.38 & 16.90 & 14.62 & 10.57 & 10.55 & 6.67 & 8.22 \\
\hline C.V & 18.38 & 24.78 & 30.16 & 28.48 & 27.56 & 28.21 & 27.23 & 24.82 \\
\hline $\mathrm{SE} \pm$ & 7.51 & 7.07 & 9.65 & 8.35 & 6.03 & 6.03 & 3.81 & 4.69 \\
\hline
\end{tabular}

$\mathrm{U}=$ Urea. FYM= Farmyard Manure. $\mathrm{CHM}=$ Chicken Manure. $\mathrm{LSD}=$ Least Significant Difference. $\mathrm{CV} \%=$ Coefficient of Variation. $\mathrm{SE} \pm=\mathrm{Standard}$ Error.

Table 3. The effect of different fertilizers on Dry Yield during (ton/ha) 2009/2010

\begin{tabular}{|c|c|c|c|c|c|c|c|c|}
\hline \multirow{2}{*}{ Treatments } & \multicolumn{8}{|c|}{ No. of Cuts } \\
\hline & 1 & 2 & 3 & 4 & 5 & 6 & 7 & 8 \\
\hline Urea (U) & 7.29 & 4.52 & 5.38 & 9.05 & 5.24 & 6.66 & 4.52 & 3.57 \\
\hline Farmyard Manure (FYM) & 5.53 & 5.33 & 7.05 & 8.95 & 6.90 & 5.57 & 4.52 & 4.53 \\
\hline Chicken Manure (CHM) & 8.24 & 8.33 & 9.05 & 14.05 & 6.43 & 5.33 & 4.76 & 4.76 \\
\hline $\mathrm{U}+\mathrm{FYM}$ & 6.67 & 4.52 & 8.48 & 11.33 & 8.09 & 6.91 & 4.76 & 6.19 \\
\hline $\mathrm{U}+\mathrm{CHM}$ & 7.76 & 7.14 & 9.28 & 8.38 & 5.62 & 5.48 & 5.24 & 5.24 \\
\hline $\mathrm{FYM}+\mathrm{CHM}$ & 7.96 & 7.76 & 12.29 & 12.14 & 8.57 & 6.43 & 4.05 & 5.48 \\
\hline $\mathrm{U}+\mathrm{FYM}+\mathrm{CHM}$ & 8.71 & 6.81 & 10.14 & 10.95 & 6.67 & 6.67 & 5.72 & 4.76 \\
\hline Control & 7.14 & 7.09 & 8.57 & 10.71 & 3.68 & 5.48 & 4.52 & 4.28 \\
\hline LSD $5 \%$ & 2.66 & 4.92 & 3.49 & 4.98 & 2.60 & 2.73 & 2.37 & 1.83 \\
\hline C.V & 20.47 & 23.60 & 22.67 & 26.58 & 22.88 & 26.35 & 28.44 & 21.51 \\
\hline $\mathrm{SE} \pm$ & 1.52 & 2.81 & 1.99 & 2.84 & 1.48 & 1.56 & 1.35 & 1.04 \\
\hline
\end{tabular}

$\mathrm{U}=$ Urea. $\mathrm{FYM}=$ Farmyard Manure. $\mathrm{CHM}=$ Chicken Manure. $\mathrm{LSD}=$ Least Significant Difference. $\mathrm{CV} \%=$ Coefficient of Variation. $\mathrm{SE} \pm=\mathrm{Standard}$ Error. 
Table 4. The effect of different fertilizers on Plant Height (cm) during2009/2010

\begin{tabular}{|c|c|c|c|c|c|c|c|c|}
\hline \multirow{2}{*}{ Treatments } & \multicolumn{8}{|c|}{ No. of Cuts } \\
\hline & 1 & 2 & 3 & 4 & 5 & 6 & 7 & 8 \\
\hline Urea (U) & 130.0 & 92.8 & 89.3 & 86.8 & 79.4 & 64.4 & 50.5 & 47.6 \\
\hline Farmyard Manure (FYM) & 122.1 & 117.1 & 106.7 & 91.2 & 77.3 & 57.6 & 45.4 & 53.6 \\
\hline Chicken Manure (CHM) & 121.4 & 97.8 & 111.7 & 100.6 & 79.8 & 70.9 & 59.5 & 48.4 \\
\hline $\mathrm{U}+\mathrm{FYM}$ & 117.4 & 96.9 & 101.8 & 88.9 & 84.5 & 66.9 & 46.4 & 47.5 \\
\hline $\mathrm{U}+\mathrm{CHM}$ & 133.3 & 110.1 & 103.3 & 94.4 & 74.8 & 60.2 & 57.4 & 63.2 \\
\hline $\mathrm{FYM}+\mathrm{CHM}$ & 126.9 & 107.1 & 116.3 & 108.9 & 89.7 & 62.5 & 45.1 & 44.1 \\
\hline $\mathrm{U}+\mathrm{FYM}+\mathrm{CHM}$ & 129.6 & 107.8 & 83.3 & 96.4 & 82.7 & 70.4 & 55.0 & 47.5 \\
\hline Control & 156.5 & 107.4 & 91.7 & 101.3 & 80.4 & 59.3 & 48.5 & 56.2 \\
\hline LSD $5 \%$ & 31.73 & 19.37 & 12.24 & 22.47 & 14.58 & 13.61 & 17.94 & 15.84 \\
\hline C.V & 13.97 & 10.57 & 7.72 & 13.36 & 10.27 & 12.28 & 20.24 & 17.72 \\
\hline $\mathrm{SE} \pm$ & 18.12 & 11.06 & 6.99 & 12.83 & 8.33 & 7.77 & 10.24 & 9.04 \\
\hline
\end{tabular}

$\mathrm{U}=$ Urea. $\mathrm{FYM}=$ Farmyard Manure. $\mathrm{CHM}=$ Chicken Manure. $\mathrm{LSD}=$ Least Significant Difference. $\mathrm{CV} \%=$ Coefficient of Variation. $\mathrm{SE} \pm=\mathrm{Standard}$ Error.

Table 5. The effect of different fertilizers on No. of Leaves/Plant during2009/2010

\begin{tabular}{|c|c|c|c|c|c|c|c|c|}
\hline \multirow{2}{*}{ Treatments } & \multicolumn{8}{|c|}{ No. of Cuts } \\
\hline & 1 & 2 & 3 & 4 & 5 & 6 & 7 & 8 \\
\hline Urea (U) & 11 & 9 & 4 & 7 & 6 & 4 & 4 & 4 \\
\hline Farmyard Manure (FYM) & 10 & 7 & 6 & 7 & 6 & 5 & 4 & 5 \\
\hline Chicken Manure (CHM) & 9 & 7 & 5 & 7 & 6 & 5 & 4 & 4 \\
\hline U+FYM & 11 & 7 & 7 & 5 & 7 & 4 & 4 & 4 \\
\hline $\mathrm{U}+\mathrm{CHM}$ & 13 & 8 & 4 & 8 & 5 & 4 & 5 & 5 \\
\hline $\mathrm{FYM}+\mathrm{CHM}$ & 9 & 8 & 7 & 6 & 6 & 5 & 4 & 4 \\
\hline $\mathrm{U}+\mathrm{FYM}+\mathrm{CHM}$ & 9 & 9 & 5 & 6 & 5 & 4 & 5 & 4 \\
\hline Control & 8 & 8 & 5 & 7 & 6 & 4 & 4 & 5 \\
\hline LSD $5 \%$ & 5.54 & 3.52 & 3.76 & 4.30 & 3.31 & 2.57 & 2.21 & 1.51 \\
\hline C.V & 31.24 & 25.36 & 23.61 & 27.99 & 32.14 & 34.49 & 29.37 & 20.50 \\
\hline $\mathrm{SE} \pm$ & 3.16 & 2.01 & 7.86 & 13.87 & 1.89 & 1.47 & 1.26 & 0.86 \\
\hline
\end{tabular}

$\mathrm{U}=$ Urea. $\mathrm{FYM}=$ Farmyard Manure. $\mathrm{CHM}=$ Chicken Manure. $\mathrm{LSD}=$ Least Significant Difference. $\mathrm{CV} \%=$ Coefficient of Variation. $\mathrm{SE} \pm=\mathrm{Standard}$ Error. 
Table 6. The effect of different fertilizers on Leaf Area Index during2009/2010

\begin{tabular}{|c|c|c|c|c|c|c|c|c|}
\hline \multirow{2}{*}{ Treatments } & \multicolumn{7}{|c|}{ No. of Cuts } \\
\cline { 2 - 9 } & 1 & 2 & 3 & 4 & 5 & 6 & 7 & 8 \\
\hline Urea (U) & 16.71 & 9.38 & 4.47 & 6.91 & 3.08 & 2.56 & 1.36 & 1.66 \\
\hline Farmyard Manure (FYM) & 14.15 & 10.80 & 9.55 & 7.01 & 2.01 & 2.92 & 0.66 & 2.71 \\
\hline Chicken Manure (CHM) & 16.50 & 12.93 & 8.64 & 11.18 & 2.88 & 3.46 & 2.96 & 2.85 \\
\hline U+FYM & 17.44 & 11.52 & 11.51 & 6.54 & 4.21 & 3.05 & 1.65 & 3.82 \\
\hline U+CHM & 20.23 & 15.24 & 8.27 & 12.97 & 2.65 & 2.92 & 2.57 & 5.07 \\
\hline FYM+CHM & 13.32 & 10.16 & 18.76 & 6.40 & 6.21 & 3.69 & 1.21 & 2.17 \\
\hline U+FYM+CHM & 14.99 & 18.01 & 11.36 & 5.27 & 2.52 & 3.05 & 1.94 & 2.66 \\
\hline Control & 11.19 & 11.91 & 10.76 & 5.95 & 2.28 & 1.79 & 0.68 & 2.75 \\
\hline LSD 5\% & 8.58 & 9.37 & 3.84 & 5.17 & 1.29 & 2.61 & 2.22 & 4.13 \\
\hline C.V & 23.49 & 22.84 & 25.88 & 27.94 & 26.63 & 25.19 & 27.92 & 29.68 \\
\hline SE \pm & 8.33 & 5.35 & 7.90 & 2.95 & 7.02 & 1.49 & 1.27 & 2.36 \\
\hline
\end{tabular}

$\mathrm{U}=$ Urea. FYM= Farmyard Manure. $\mathrm{CHM}=$ Chicken Manure. $\mathrm{LSD}=$ Least Significant Difference. $\mathrm{CV} \%=$ Coefficient of Variation. $\mathrm{SE} \pm=\mathrm{Standard}$ Error.

Table 7. The effect of different fertilizers on Leaf to Stem Ratio during2009/2010

\begin{tabular}{|c|c|c|c|c|c|c|c|c|}
\hline \multirow{2}{*}{ Treatments } & \multicolumn{8}{|c|}{ No. of Cuts } \\
\hline & 1 & 2 & 3 & 4 & 5 & 6 & 7 & 8 \\
\hline Urea (U) & 1.27 & 0.79 & 0.65 & 0.89 & 0.71 & 0.68 & 0.69 & 1.35 \\
\hline Farmyard Manure (FYM) & 1.26 & 0.81 & 0.90 & 0.92 & 0.70 & 0.80 & 2.24 & 1.80 \\
\hline Chicken Manure (CHM) & 0.95 & 0.85 & 0.81 & 0.78 & 1.31 & 1.22 & 1.41 & 1.66 \\
\hline U+FYM & 1.27 & 0.66 & 0.80 & 0.78 & 0.88 & 1.13 & 0.81 & 1.82 \\
\hline $\mathrm{U}+\mathrm{CHM}$ & 0.99 & 0.87 & 0.90 & 0.92 & 0.64 & 0.70 & 1.52 & 1.03 \\
\hline $\mathrm{FYM}+\mathrm{CHM}$ & 0.92 & 0.83 & 0.71 & 0.87 & 1.04 & 0.70 & 1.15 & 1.11 \\
\hline $\mathrm{U}+\mathrm{FYM}+\mathrm{CHM}$ & 0.95 & 0.75 & 0.78 & 0.94 & 0.64 & 0.75 & 0.73 & 0.99 \\
\hline Control & 1.08 & 0.77 & 0.64 & 1.09 & 0.87 & 0.93 & 0.69 & 1.02 \\
\hline LSD $5 \%$ & 0.45 & 0.31 & 0.31 & 0.50 & 0.79 & 0.58 & 1.48 & 1.40 \\
\hline C.V & 23.39 & 22.06 & 22.72 & 31.67 & 23.06 & 28.37 & 23.03 & 29.50 \\
\hline $\mathrm{SE} \pm$ & 0.25 & 0.17 & 0.18 & 0.28 & 0.45 & 0.33 & 0.85 & 0.80 \\
\hline
\end{tabular}

$\mathrm{U}=$ Urea. $\mathrm{FYM}=$ Farmyard Manure. $\mathrm{CHM}=$ Chicken Manure. $\mathrm{LSD}=$ Least Significant Difference. $\mathrm{CV} \%=$ Coefficient of Variation. $\mathrm{SE} \pm=\mathrm{Standard}$ Error. 
--Plant height, number of leaves per plant, leaf area index and leaf to stem ratio were not significantly affected by fertilizers (Table 1, 2, 3, 4, 5, 6 and 7). The non significant response of the crop obtained in this study may be due to the previous experiments in the site and the different agronomic practices done on it. A similar finding was reported by Brima (2007), who stated that mean plant height, leaf area index and leaf to stem ratio of rhodes grass were not significantly affected by NPK and Abedelrahman (2007) who reported that no significant effect of nitrogen fertilizer was detected on mean plant height in the first and second cuts. In this regard, the highest plant density and dry yield were obtained with (CHM) fertilizers but the highest fresh yield was obtained with (FYM+CHM). Similar findings were reported by Hassan (2002) who reported that the highest yield of both Abusabien and Pioneer 988 was obtained with chicken manure and Omer (1998) who reported that manure alone or mixed with the urea resulted in an increase in growth attributes. The C.V. for table 1 for the latest cuts was higher than normal which might be due to the variation in cutting time and/or season as Rhodes is slow on growth during winter and cut scheduling was based on fixed days $(30$ days).This was reflected in the high LSD for the same table but the numbers were less than the treatments mean.

\section{REFFRENCES}

[1] Mohammed, H.M. (2000). Pasture in Sudan ways of support and development. Paper presented in the conference for the role of ranchers in the development of pastoral sector. Jeddah, Saudi Arabia. (In Arabic). Cited by Adam, M.Y. (2004).

[2] Obied, K.A. (2003). Effect of Draby Rhizobia, Chicken Manure, Sulphur, and their Residual Effect on Nodulation, Growth, Yield, and Seed Quality of Soybean and Hyacinth Bean. Ph.D. Thesis. Faculty of Agriculture, University of Khartoum, Sudan.

[3] Omer, E.A. (1998). Effect of Farmyard Manure and Urea Fertilization on the Growth and Forage Yield of tow Maize (Zea mays L.). Cultivars. M.Sc. Thesis. Faculty of Agriculture, University of Khartoum, Sudan

[4] Reed, C.F. (1976). Information Summarizes on 1000 Economic Plant. Typescripts Submitted to the USDA.

[5] Saad, H.H. (2009). Evaluation of Nitrogen Fertilizers on Quality and Quantity of Rhodes Grass (Chloris gayana L. Kunth). M.Sc. Thesis. Faculty of Agriculture Studies, Sudan University of Science and Technology, Sudan.

[6] Valenzuela, H. And Smith, J. (2002). Rhodes Grass, Sustainable Agriculture, Cover Crops/SA-CC-3. Cooperative Extension Service, Collage of Tropical Agriculture and Human Resources. University of Hawaii at Manoa web site: www.ctahr.hawaii.ed

[7] Abass, E.A.H. (2007). Effect of Chicken and Farmyard Manure on Growth and Yield of Forage Sorghum Cultivars (Sorghum bicolor (L.) Moench and Sorghum sudanense). M.Sc. Thesis. Faculty of Agriculture, University of Khartoum, Sudan.

[8] Abdelrahman, F.I. (2007). Effect Seed Rate and NPK Fertilization on Growth and Yield of Forage Quality of Rhodes Grass (Chloris gayana L. Kunth). M.Sc. Thesis. Faculty of Agriculture, University of Khartoum, Sudan.

[9] Adam, H.S. (1996). The Agriculture Climate. Dar Alassala Publication. 1st ed. P57 (Arabic).

[10] Borhan, H. And Hago, T.E. (2000) Principle of Crop Production. University of Khartoum Printing Press, Sudan (Arabic addition).

[11] Brima, F.I.A. Effect of Seed Rate and NPK Fertilization on Growth, Yield and Forage Quality of Rhodes grass (Chloris gayana L. Kunth). M.Sc. Thesis. Faculty of Agriculture, University of Khartoum, Sudan.

[12] El Basari, A.M. (1999). Effect of Natural Amendments and Aggregates Stability and Water Flow in Different Soils. M.Sc. Thesis. Faculty of Agriculture, University of Khartoum, Sudan.

[13] Elawad, G.E. (2004). Effect of Chicken Manure and Urea Fertilizer on Growth and Yield of Teff Grass (Evagrostis teff Zucc.) M.Sc. Thesis. Faculty of Agriculture, University of Khartoum.

[14] Elzelal, H.A. (2002). Effect of Chicken Manure and Season on the Performance and HCN Content of Two Forage Sorghum Cultivars. M.Sc. Thesis. Faculty of Agriculture, University of Khartoum, Sudan.

[15] FAO, (2006). Fertilizer Use by Crops. Food and Agriculture Organization of the United Nations. Vol. 17.

[16] Gasim, S.A. (2001) Effect of Nitrogen, Phosphorus and Seed Rate on Growth, Yield and Quality of Forage Maize (Zea mays L.). M.Sc. Thesis. Faculty of Agriculture, University of Khartoum, Sudan.

[17] Hassan, E.A.H. (2002). Effect of Chicken Manure and Season on the Performanceand HCN Content of two Forage Sorghum Cultivars. Ph.D. Thesis. Faculty of Agriculture, University of Khartoum, Sudan.

[18] Irshad, M.; Yamamoto, S.; Ereji, A.E.; Endo, T. and Hona, T. (2002). Urea and manure effect on growth and mineral content of maize under saline conditions. Journal of plant nutrition. Volume 25: 189-200.

[19] Ismail, F.M. (2007). Effect of Different Rate of Chicken Manure on the Growth and Yield of Forage Sorghum (Sorghum bicolor L.). M.Sc. Thesis. University of Khartoum, Sudan.

[20] Khair, M.A.M. (1999). Principle of Forage Crops Production. Agricultural Research Corporation ARC, Training and Publication Administration, Wad madani, Sudan. (In Arabic). 